\title{
Da'wah Communication and Social Media: The Interpretation of Millennials in Southeast Asia
}

Submitted 25/04/20, 1st revision 30/05/20, 2nd revision 27/06/20, accepted 15/08/20

\author{
Rizki Briandana ${ }^{1}$, Caturida Meiwanto Doktoralina ${ }^{2}$, \\ Shahir Akram Hassan ${ }^{3}$, Wan Norhaniza Wan Hasan ${ }^{4}$
}

\begin{abstract}
:
Purpose: The purpose of this study is to analyse the perspectives of millennials interpreting da'wah communication through social media. The presence of new media in digital platforms has become an alternative medium for accessing information and entertainment.

Design/Methodology/Approach: The study uses a case study methodology with in-depth interviews as the method of data collection. A total of nine audiences were informants from Indonesia, Malaysia, and Brunei.

Findings: The results indicate that the flexible quality of the social media entrenched in YouTube enables its audiences - especially the millennials - to see and listen to preachers or study da'wah in any location at any time.

Practical Implications: The study can contribute to promoting Islamic development in social media, e.g., YouTube channel.

Originality/Value: This study contributes to compiles prior research and contributes among other digital media; YouTube has become a famous source of information. In light of the current media development, Da'i (a person engaging in da'wah) can use YouTube as a means of preaching (da'wah) and YouTube becomes an alternative media for millennials with a wide selection of proselytizing video content.
\end{abstract}

Keywords: Communication, information and knowledge, marketing, promotion.

Paper Type: Research Article. JEL Code: D8, M15, M21, N30.

\section{Acknowledgements:}

The authors would like to thank the Research centre of Universitas Mercu Buana, Centre for Islamic Development Management Studies (ISDEV) University Sains Malaysia, Ministry of Education and Culture Republic of Indonesia, especially the Academic Assessor team of Dikti, for their assistance and consulting for this publication.

\footnotetext{
${ }^{1}$ Fakultas Ilmu Komunikasi, Universitas Mercu Buana, Jakarta.

E-mail: rizki.briandana@mercubuana.ac.id

${ }^{2}$ Corresp author, Fakultas Ekonomi dan Bisnis, Universitas Mercu Buana, Jakarta.

Email: caturida_meiwanto_drm@mercubuana.ac.id,chess302@gmail.com

${ }^{3}$ Centre for Islamic Development Management Studies (ISDEV), University Sains Malaysia.

E-mail: shahirakram@usm.my

${ }^{4}$ As in 3. E-mail: wanhaniza@usm.my
} 


\section{Introduction}

Social media, also known as social networking, is part of the new media (refers to any digital media that is interactive and digitally distributed). Social media removes human barriers from socializing (Haftor and Mirijamdotter, 2011) and is not affected by the limits of time and space. Social media allows humans to communicate with each other wherever they are (no matter the physical distance) at any time (Gane and Beer, 2008). As web 2.0 platforms, social networking sites offer users interactivity and are the most popular on the Internet (Goh, Heng, and Lin, 2013). The second generation of web-based services is characterized by consumer-generated content (CGC) that allows people to share information (Dwityas and Briandana, 2017).

Social media can provide great benefits if it is used properly (Anderson and Jiang, 2018). $D a^{\prime}$ wah is an activity that invites people to believe and obey God in accordance with the lines of aqeedah (creed) and shari'ah (Islamic morals). Social media can also be used to communicate da'wah (Fakhruroji, 2017). An understanding of the characteristics of media users and their interests (whether they are fullfiled or not) can help develop the principle of $d a$ 'wah via social media (Thaib, 2019) because social media can turn everyone into a mass communicator (Bakti, 2003). Each individual can be a guest speaker and become a preacher without having to go through the mainstream media (e.g., television, radio and print media).

The characteristics of this mass media can be used for good and evil. Social media can present true and false information that either intends to promote the common good or gain personal benefits (Gane and Beer, 2008). When social media users choose their reading material (their favorite content e.g., lectures, politics, news, etc.), then for their favourite reading purposes they tend to choose to follow the information that is suited to their taste, although it may not necessarily be good or right (Haftor and Mirijamdotter, 2011). Understanding the characteristics of social media users is important to develop da'wah online (Hew, 2018). Da' $i$ can lead effective interaction by understanding social media users' interests (which can provide direction to the $d a$ 'wah approach) in order to preach specific material (Omar et al., 2015).

The change in new media is increasingly great for a community. Various studies have proven how much societal influence new media has, especially on the younger generation (Briandana and Dwityas, 2019). The exploitation of new media began to threaten the existence of an objective perspective and public space. Its presence can reduce our connection. Along with the industrial revolution 4.0, the Internet has become a new medium to define and shape our reality, and accessing YouTube is a prominent learning method (Suhaimi, 2012; Khan and Vong, 2014).

YouTube content has a large role in disseminating information - making it easier for students and teachers to understand learning material (Moor et al., 2010). In previous years, YouTube was not as popular as other content or channels as a learning medium in particular (Cunningham et al., 2016). However, a lot of content on YouTube which 
was not special at first (nor was it uploaded as a learning medium) can be used as a learning medium (Feroz Khan and Vong, 2014). As Internet network technology widens its accessibility, YouTube can be used as a medium to deliver information on a given subject matter (Rahmi et al., 2016).

In Islamic terms, the message of $d a$ 'wah must be conveyed by the $d a^{\prime} i$ (the subject of $d a$ 'wah) to the mad'u (the object of $d a$ 'wah), which is the whole teaching of Islam in the book of Allah and the sunnah of the Prophet. It is also called al haq (ultimate truth); that is, Islam sourced from the Qur'an (Murthado, 2017). Thus the message of Islam is an order, advice, mandate, or request delivered in material form from the $d a^{\prime} i$ (communicators) to the mad'u (communicants) based on the Qur'an and al-Hadith.

$D a$ 'wah is the process of ameliorating the negative conditions (thoughts, feelings, behaviours) of a person or society (Nisa, 2018). Specifically, the da'wah of Islam is defined as an activity to call or invite humans to change to prevent ignorance (Weng, 2018). Based on the explanation above, $d a$ 'wah activities can succeed if optimally supported by an effective communication process. The communicator or preacher must also pay attention to his or her appearance and the message to be conveyed to the mad' $u$ so that an active communication process is established (Bakti, 2003).

In this context, the existence of a digital media platform becomes a means of $d a$ 'wah communication for adolescents (Thaib, 2019). The male teachers (asatidz) and female teachers (asatidzah) as the $d a$ ' $i$ take advantage of its open access to conduct lectures and preach in various mosques or on study sites where the study session can be later uploaded to YouTube and watched repeatedly by many audiences (Slama, 2017).

The principle of digital media is to utilize all available platforms, including social media (Ioanid and Scarlat, 2017; Mulyana, Briandana, and Rekarti, 2020). YouTube has become an alternative to Instagram for delivering information and entertainment (Goh et al., 2013). Da'i currently use YouTube as a means of $d a$ 'wah communication for teenagers with a wide selection of preaching video content (Majid and Noor, 2017; Slama, 2017). This study will analyse how Indonesian, Malaysian and Bruneian millennials interpret $d a$ 'wah communication through social media, namely YouTube, and how it can be optimized.

\section{Conceptual Framework of the Study}

\subsection{Da'wah Communication}

In principle, da'wah is an activity targeting individuals to follow and practice the teachings of Islam (Fakhruroji, 2017). This invitation is carried out by approaching targets according to their characteristics and their tendencies. The nature of the media to be used and the character of its user community needs to be understood because differences in user culture affect the strength of the effects of the use of social media (DeNardis and Hackl, 2015). 
$D a$ 'wah communication is the process of delivering information or messages (from a person or group of people) sourced from the Qur' an and al-Hadith using symbols (both verbally and nonverbally) with the aim of changing the attitudes, opinions, or behaviour of other people. $\mathrm{Da}$ 'wah works according to Islamic teachings both directly and indirectly, orally and through the media, respectively (Majid and Noor, 2017).

According to Hassan (2016) and Thaib (2019) there are many definitions of da'wah; for example, a da'wah message can be verbal and nonverbal. A $d a$ 'wah can be referred to as the contents of messages or material (Maddah) based on aql (the reason) and wahyu (the revelation). Planning such messages can be done using the rhetorical tradition i.e., communication skills to develop oneself in arguing and debating (Nisa, 2018; Omar et al., 2015).

In the development of the science of $d a$ 'wah, tabligh is defined as a form of $d a$ 'wah that conveys the teachings of Islam through pulpit media and mass media (both electronic and print), targeting many audiences. In principle, the activities of tabligh are continuous, and Muslims have an obligation to continue implementing them throughout their entire lives (Bakti, 2003; Yusoff and Hassan, 2020).

\subsection{New Media}

One communication theory that explains the phenomenon of media use is known as the New Media Theory (Gane and Beer, 2008). It holds the point of view that the audience is an active party. Here the Internet is seen as a driving factor for changes in communication within a community. The concept of new media or what is commonly referred to as the second media era draws our attention to new forms of media use ranging from individual information and knowledge ownership to interaction (Haftor and Mirijamdotter, 2011).

New media theory is one of the theories in the sociocultural tradition. In 1990, Mark Poster launched his big book, The Second Media Age (Littlejohn and Foss, 2009). This marked a new period in which interactive technology and network communication, particularly cyberspace, would change society. The second media era has four components: (1) decentralization; (2) bi-directional characteristics; (3) an out of control situation; (4) democratization; (5) elevated individual awareness; (6) individual orientation (Gane and Beer, 2008).

\subsection{Social Media for Da'wah Communication}

The term "media" comes from the Latin (medius) word for "between" or "intermediaries" connect information between the source and its recipient. Baran and Davis (2011) define the media as a means of communication. According to McQuail (2010), the media are information and communication channels that have a great influence on society. Indeed, interpersonal, group, public, and organizational communication are special clusters in the theory of mass communication. 
Theories that discuss the media themselves are inseperable from the historical differences between the specifiying the time frames for these ages. The nature of interactivity typical of the second media age, for example, tends to be bi-directional in communication whereas the first media age had only one-sided communication (Bryant and Miron, 2004).

Accessing social media for communication is a new theory and practice used by the wider community as a way to obtain information and gain new knowledge; for example, pedagogical activities or assignments outside the classroom (Haftor and Mirijamdotter, 2011). However, this study is limited to the problems of Islam. The phenomenon of da'wah on the Internet today has provided a new paradigm for its success i.e., strategies to incorporate transmedia storytelling elements such as Internet, serious games, video, like studies relating to hashtags in social media to increasing engagement of the audience (Doktoralina et al., 2020). Da'i is no longer the main factor influencing mad'u. In the context of the networked society, mad'u does not only passively accept the messages preached by $d a^{\prime} i$. Instead, they actively process and interpret the messages they receive but are often not affected by the identity of the messenger. There is no longer a $d a^{\prime} i$ (author) or mad'u (reader) but the two roles have merged in the same status of the user. Users are not only able to consume and employ information, but also can produce and distribute it.

Authority is no longer concentrated on or controlled by the preacher but also the $m a d^{\prime} u$. They too are capable of reproducing the religious messages they receive for later distribution. When we receive religious messages online that we think may be useful to friends, relatives, and colleagues, some of us will immediately share them via various Internet platforms. In fact, we can voluntarily produce religious messages even though we are not really preachers. The omnipresence of the Internet cannot be avoided because it has become a new civilization in the world of information and communication on a global level. So much more information can be feasibly accessed by the public for personal, educational, religious, and business interests. Mad' $u$ are Internet users who not only look for information but share what they receive through social media and add other religious messages as appropriate (according to what they understand).

The existence of the Internet as a medium for $d a$ 'wah has become a necessity. Scholars, preachers, and Islamic leaders must immediately take strategic steps to guard and nurture the young generation to be ready and mature in the face of negative attacks from Internet media. One way to deal with negative Internet attacks is by creating networks about Islam, including cyber-Muslim (or cyber- $d a$ 'wah) sites and blogs. Social networks like Facebook, Instagram and Twitter may also be used. Each of these cyber sites presents Islamic information using various methods (Fakhruroji, 2017). Thus, when the mad'u (the netizens in this context) search for religious materials through the Internet, they can easily get that information through Islamic da'wah sites. However, they need to be wary of sites in the name of "Islam" that contains material far from actual Islamic teaching provisions. Nevertheless, $d a$ 'wah 
through the Internet is considered very effective to penetrate the boundaries of space and time at a relatively affordable cost (Fakhruroji, 2017). These factors make preaching messages through the Internet the people's choice. They are free to choose the $d a$ 'wah material they like and avoid coercion. Diversification of $d a$ 'wah delivery has allowed it to reach broader segments (e.g., using a website mailing list feature to invite religious discussion or send moral messages). $D a$ 'wah through the Internet is considered very effective because mad' $u$ are interactive and critical netizens.

\section{Methodology}

This research used a case study, a comprehensive method for understanding individuals (and the problems they face). Its goal is to resolve problems and promote good self-development (Yin, 2013).

The primary data in this study was conducted by interviewing informants and interacting with millennials from Indonesia, Malaysia, and Brunei Darussalam. A total of nine people were informants in this study who were selected based on pilot research (i.e., they were millennials active on social media who participated in religious activities). The collection techniques were interviews and observation. The secondary data is an examination of the data collection techniques. Participant observation was specifically carried out by observing informants' interactions and accessing their sites/social media.

\section{Results and Discussion}

\subsection{Results}

Today, we see how the media has a dominant power to influencing every dimension of human life. With the development of information and communication technology (ICT), the media in the virtual positions the recipient as an active communicant an active party. The massification of communication "will be mixed with demassification" in which websites are forms of interactive communication as well as mass communication (Majid and Noor, 2017). Communication studies involve a source of information, a message, a channel, a receiver, and an effect. When these key concepts are applied to Islamic studies, we can see, one by one, what emerges as relevant.

Islamic communication emphasizes the existence of Islamic values from the communicator to the recipient in accordance with the Qur'an and Al-Hadith. Tehranian (1988) revealed that from the Islamic perspective, communication must be developed through Islamic worldviews (tasawwur; e.g., the idea that absolute power belongs only to God). Besides Allah as the ultimate focal point of the Islamic worldview, tasawwur also entails the role of His subjects (Hasan et al., 2014). Therefore, when discussing Islamic communication, the role of ulama and mosque 
institutions that communicate and supervise sharia supporting Muslim life "is crucial" (the role is crucial).

Da'wah communication has long existed in the daily lives of those who practice it. With rapid developments in technology and online media, it is very easy to reach any community. The public can access lectures from preachers and other missionary communication on whatever social media they prefer. One of the most commonly used is YouTube. It differs from other social media because there is no time limit for videos, so the general public can listen to religious studies freely. Some of the da'wah studies that have been uploaded on YouTube include Ustadz Abdul Somad (UAS), Ustadz Hanan Attaki, Ustadz Zakir, etc.

The results of interviews with Indonesian informants shows that most of them liked the lecture of Ustadz Abdul Somad. One of the informants responded that aside from the delivery of his lecture (which was fun and easy to understand), he liked how the material was based on his book, so after listening to his lecture on YouTube, he could open the book in order to understand more. Not all of the religious content uploaded to YouTube is in the form of lectures in front of a congregation, there are also other collections of videos. The message remains the same (preaching about the science of religion) and it is no less exciting to watch or listen to.

Here are some additional responses on social media from personal communication with informants:

1. We can use this social media as an insight into the tools of $d a$ 'wah but we must not [forget] the most basic thing; namely, learning with the Uztads ... at home, at the mosque, etc. As for YouTube, this is a solution for enhancing our insight [that] encourages us to be more active in studying religious knowledge at any time.

2. Da'wah media can be obtained from anywhere. [There is] Instagram, Facebook, YouTube etc., [which] are legitimate because there is one Uztad who has stage fright when it comes to majlis ta'lim (teaching place) and he prefers YouTube for his lectures.

3. YouTube is very effective for preaching as a forum for millennials who like to watch YouTube.

Malaysian informants stated that "religious content through social media is better, more interactive, faster, and easier to find," not to mention "more relaxed." Information is "more accessible (all at your fingertips)," and the follower function makes it easier for all users to attend to notifications." Said another informant: "I use YouTube almost five hours a day, [not always] for religious content... but if there are questions about religion, I will find materials on social media about the issues I want." One Malaysian informant found social media better than conventional media for religious content because "the information is delivered more quickly, $[\ldots]$ can be disseminated more widely, and the cost of the spread of information is low." 
In the context of the content delivered by $d a^{\prime} i$ through social media, a Malaysian informant stated that:

1. An ustadz [who is] good in the media is a cleric who uses good language, is not talkative, is not rude, always updates new science in accordance with the present-day following of the views of scholars and a jurist (fuqaha'), and is simple, not extreme.

Good delivery, according to another Malaysian informant, is based on the "true characteristics of Muslims" - no violence, being "full of courtesy when reprimanding," proper pronunciation, referencing all issues concerning religious laws based on the Qur'an and al-Hadith, and not being involved "with any political direction."

Meanwhile, informants from Brunei Darussalam also stated their interpretations of the delivery of religious content through social media:

1. The content of religion conveyed through social media is effective because the content delivered is not accepted so simply; it needs to be investigated to validate whether [it] is true ... So we not only get knowledge through social media but we also become people who are diligent in finding the right things.

2. With the ease of initially accessing this content or [downloading] the content, it [can be] examine[d]. These contents are not merely giving religious warnings, they can also be studied and used as motivation to practice every day.

3. Social media is the latest channel for information acquisition. And one of the easy and modern ways for religious activists to spread $d a$ 'wah and for social media users to accept the preaching [without thinking] about the time and place.

They noted that there was no problem with religious messages on the internet "as long as the element of $d a$ 'wah is not contrary to the teachings of Islam." They said "the only difference" between traditional communication methods and the Internet "is the speed of obtaining the religious message." Brunei informants also commented on the type of the content delivered by Ustadz on social media that would be well received by the public:

1. For me, Ustadz should have an amusing element because it is more easily accepted than a serious delivery. Do not insinuate a person or group... There are half-Islamic religious teachers in Malaysia that draw on political experts/celebrities to make the audience laugh.

2. Ustadz who are good in the media are those who deliver [messages] in a modest way. The contents of the da'wah [do not] merely touch [on] religious chapters but also need to be related to the issue of early matters combined with the Islamic view so that [the ustadz] may give warnings and be close to the hearts of users of social media so that they can appreciate the religious elements 
conveyed indirectly ... Ustadz also need to maintain their appearance so that they can be an example [for] the audience. [They should not] joke too much while delivering da'wah.

\subsection{Discussion}

The $d a^{\prime}$ wah effect is feedback from the $d a^{\prime}$ 'wah process. According to Bandura (2001) and Marlow, Lacerenza, and Salas (2017), effects occur at the cognitive level if there are changes in what is known, understood, and perceived by the public (based on the transmission of knowledge, skills, beliefs, or information). Affective effects arise if there is a change in what is felt, liked, or hated by the public, which includes everything related to emotions, attitudes and values. Finally, behavioural effects refer to real observable behaviours (e.g., patterns of actions, activities, or habits).

$D a$ 'wah communication is effective if the recipient adopts certain attitudes conveyed by the communicator. The process of receiving messages depends on experience, social culture, individual characteristics, and the psychological audience. In mass communication literature, hypodermic needle theory assumes that conventional media are considered smarter than the audience. The audience, members of the community, is an active audience so that there is no interference between the message and the recipient; the message that has been distributed to the public is directly received and accepted by the target without an intermediary. This theory assumes that the audience can interpret the message conveyed by the media according to their social, economic, cultural and political background.

If we look at the process of communication, there is essentially no difference between Islamic $d a$ 'wah and non-Islamic communication in terms of models, processes, and effects, only the philosophical foundation. The philosophy of Islam uses the Qur'an, the al-Hadith, and the opinions of scholars so that the essence of any information broadcast remains the same no matter the model.

\section{Conclusion}

This research concludes that in the context of technological developments, social media can be used as a means of $D a$ 'wah communication for teenagers. YouTube is in the spotlight of teenagers on social media and anyone can see and listen to da'wah studies/lecture at any time from any location. YouTube adds insight to content in any field, especially for teenagers. However, when preaching through social media, there are obstacles. In addition to the demands of facilitating digital audiences, informants lament that there is no direct interaction (when there is material that cannot be understood in the study, questions to the Ustadz cannot be asked directly).

\section{References:}

Anderson, M., Jiang, J. 2018. Teens, social media and technology. Pew Research Center, 31. 
Bakti, A.F. 2003. Communication and Dakwah: Religious Learning Groups and Their Role in the Protection of Islamic Human Security and Rights for Indonesian Civil Society. In Comparative Education, Terrorism and Human Security, 109-125. Springer.

Bandura, A. 2001. Social cognitive theory of mass communication. Media Psychology, 3(3), 265-299.

Baran, S.J., Davis, D.K. 2011. Mass Communication Theory: Foundations, Ferment, and Future. Cengage Learning.

Briandana, R., Dwityas, N.A. 2019. Media literacy: An analysis of social media usage among millennials. International Journal of English Literature and Social Science, 4(2), 488496. https://doi.org/10.22161/ijels.4.2.44.

Bryant, J., Miron, D. 2004. Theory and Research in Mass Communication. Journal of Communication, 54(4), 662-704.

Cunningham, S., Craig, D., Silver, J. 2016. YouTube, multichannel networks and the accelerated evolution of the new screen ecology. Convergence, 22(4), 376-391.

DeNardis, L., Hackl, A.M. 2015. Internet governance by social media platforms. Telecommunications Policy, 39(9), 761-770.

Doktoralina, C.M., Bahari, Z., Hassan, S.A., Ismail, N.A., Mardiyah, S.A.L. 2020. Hashtags as a way to expedite the zakat supply chain. Uncertain Supply Chain Management, 8(1), 197-206. https://doi.org/10.5267/j.uscm.2014.5.002.

Dwityas, N.A., Briandana, R. 2017. Social media in travel decision making process. International Journal of Humanities and Social Sciences, 7(7), 291-292.

Fakhruroji, M. 2017. Dakwah di era media baru: Teori dan aktivisme dakwah di internet. Dakwah Di Era Media Baru: Teori Dan Aktivisme Dakwah Di Internet, (2), 1-150.

Feroz Khan, G., Vong, S. 2014. Virality over YouTube: an empirical analysis. Internet Research, 24(5), 629-647.

Gane, N., Beer, D. 2008. New Media The Key Concept. Oxford and New York, Berg.

Goh, K.Y., Heng, C.S., Lin, Z. 2013. Social media brand community and consumer behavior: Quantifying the relative impact of user-and marketer-generated content. Information Systems Research, 24(1), 88-107.

Haftor, D.M., Mirijamdotter, A. 2011. Information and Communication Technologies, Society and Human Beings: Theory and Framework. Hershey and New York: Information Science Reference.

Haftor, Darek, Mirijamdotter, Anita. 2010. Information and Communication Technologies, Society and Human Beings: Theory and Framework. Hershey and New York, Information Science Reference.

Hasan, W.N.W., Hanapi, M.S. 2014. Analisis Acuan Indeks Pembangunan. Global Journal Al-Thaqafah (GJAT), 4(1), 113-126.

Hassan, S.A. 2016. The Use of Logic in Contemporary Islamic Discourses. Mediterranean Journal of Social Sciences, 7(5), 171. https://doi.org/10.5901/mjss.2016.v7n5p171.

Hew, W.W. 2018. The Art of Dakwah: social media, visual persuasion and the Islamist propagation of Felix Siauw. Indonesia and the Malay World, 46(134), 61-79.

Ioanid, A., Scarlat, C. 2017. Factors influencing social networks use for business: Twitter and YouTube analysis. Procedia Engineering, 181, 977-983.

Littlejohn, S.W., Foss, K.A. 2009. Encyclopedia of Communication Theory, Vol. 1. London, Sage.

Majid, A.A., Noor, A.M. 2017. De-Westernization of Social Media Dependency for Da'wah Purposes. Al-'Abqari: Journal of Islamic Social Sciences and Humanities, 12, 35-46.

Marlow, S.L., Lacerenza, C.N., Salas, E. 2017. Communication in virtual teams: A conceptual framework and research agenda. Human Resource Management Review, 
27(4), 575-589.

McQuail, D. 2010. Mass Communication Theory. London and New York, Sage publications.

Moor, P.J., Heuvelman, A., Verleur, R. 2010. Flaming on youtube. Computers in Human Behavior, 26(6), 1536-1546.

Mulyana, A., Briandana, R., Rekarti, E. 2020. ICT and Social Media as a Marketing Communication Platform in Facilitating Social Engagement in the Digital Era. International Journal of Innovation, Creativity and Change, 13(5), 1-16.

Murthado, A. 2017. The empowerment of social media for da'wah in Medan city'. IOSR Journal of Humanities and Social Science (IOSR-JHSS), 22(4), 86-93.

Nisa, E.F. 2018. Social media and the birth of an Islamic social movement: ODOJ (One Day One Juz) in contemporary Indonesia. Indonesia and the Malay World, 46(134), 24-43.

Omar, F.I., Hassan, N.A., Sallehuddin, I.S. 2015. Role of Social Media in Disseminating Dakwah (Peranan Media Sosial dalam Penyebaran Dakwah). In Islamic perspectives relating to business, arts, culture and communication, 43-55. Springer.

Omar, R., Bahrom, H., De Mello, G. 2015. Islamic perspectives relating to business, arts, culture and communication. Role of Social Media in Disseminating Dakwah (Peran Media Sosial Dalam Penyebaran Dakwah), 43-55. Singapore, Spinger.

Rahmi, Y., Sekarasih, L., Sjabadhyni, B. 2016. The influence of beauty vlog on perceived source credibility and purchase intention. Makara Hubs-Asia, 20(2), 13-23.

Slama, M. 2017. Social media and Islamic practice: Indonesian ways of being digitally pious. Digital Indonesia: Connectivity and Divergence. Singapore: ISEAS Publishing, 146162.

Suhaimi, S. 2012. [en] Dakwah and Communication Programmes in Tertiary Higher Education in Indonesia: A Brief Survey. Islāmiyyāt, 34.

Tehranian, M. 1988. Communication theory and Islamic perspectives. Communication Theory: The Asian Perspective, 190-203.

Thaib, E.J. 2019. Da'wa, Social Media and Challenge the Mainstream of Islam among Millennial Generation. In Proceedings of International Conference on Da'wa and Communication, Vol. 1, 101-109.

Weng, H.W. 2018. On-Offline Dakwah: Social Media and Islamic Preaching in Malaysia and Indonesia 1. In Mediatized Religion in Asia, 89-104. Routledge.

Yin, R.K. 2013. Applications of case study research. Applied Social Research Methods Series. https://doi.org/10.1097/FCH.0b013e31822dda9e.

Yusoff, S.Z., Hassan, S.A. 2020. Islamic-Based Public Relations: Implementation In Muslim-Friendly Hotels In Malaysia. Journal of Talent Development and Excellence, 12(2s), 673-683. 